\title{
STRATEGY FOR SOIL PROTECTION IN CROSS-BORDER REGION OF HUNGARY AND ROMANIA
}

\author{
János Lazányi, Gábor Demeter \\ University of Debrecen, Hungary
}

\begin{abstract}
Within the Hungary-Romania Cross-Border Co-operation Programme for 2007-2013 the University of Debrecen and the University of Oradea is to elaborate a soil strategy for the Nyírség and Bihor Mts region. Project partners expect the strategy will support and strenghten national, regional and local soil policies and contribute to the competitiveness of the region by protecting and developing various soil functions. Project partners also expect to prevent cross-border problems with soil and reduce the competition caused by cost differences. The elaboration of the strategy includes the problems of erosion, deflation, compaction, water-deficiency, inland water-threat, problems induced by the usage of fertilizers, loss and substitution of soil organic matter, amelioration (bentonite, sewage sludge, fermented biogas). Based on summarised data of former examinations and new experiments a concise database will make it possible to calculate and apply the Sustainability Index Model, which may be useful in order to address EU supports properly based on objective calculations, and may be useful to determine the optimal culture. The project also encourages the farmers to keep in mind the cross-compliance, since EU gives financial support to realise sustainable soil strategy based on EU directives. This may enhance the options to initiate the take off of rural areas with shrinking export facilities, to mitigate social tensions and the effect of migration processes.
\end{abstract}

Key words: ???

\section{Introduction}

The European Commission adopted proposals for a Soil Framework Directive under the Thematic Strategy for Soil Protection on September 22, 2006. The comprehensive strategy takes into account all the different functions that soils can perform, their variability and complexity, and the range of different degradation processes, while also considering socio-economic aspects. Hungary-Romania Cross-Border Co-operation Programme for 2007-2013 is based on the results and experiences of the past Interreg IIIA in Hungary and Phare CBC programmes in Romania. The goal is to bring the people, communities and economic actors of the border area closer to each other in order to facilitate the joint development of the co-operation area, building upon the key strengths of the border region. The programme provides for two Priority Axes, such as (i) improvement of the key conditions of joint, sustainable development in the cooperation area, and (ii) strengthen social and economic cohesion of the border area, which reflect the main streams of cooperation. This means, that cross-border region of Hungary and Romania is ahead of the game and establish firm bases for co-operation. The project entitled "Elaboration of a Sustainable Soil Strategy for the Nyírség and Bihor mountain region" is a good example of cross-border cooperation to enhance and realise EU politics. The goal of the project is to elaborate a sustainable soil strategy for two landscapes of different characteristics (hilly region and sandy plains), both with disadvantageous social and physical geographical background in accordance with Soil Framework Directive, COM (2006:232) and Soil Thematic Strategy, COM (2006: 231).

\section{Background to the project}

Soil can be considered a partly-renewable resource, as it takes hundreds of years to produce a few centimetres of fertile layer, yet soil degradation is accelerating in many regions of the European Union. Some threats are naturally occurring such as erosion by water or wind. Other soil problems are linked to industrial sites, mining, illegal or poorly managed landfills, sewage sludge, and certain agricultural practices. Some problems are linked to the sealing of soil for housing, roads and other infrastructural purposes, and the effects of floods and landslides. Soil degradation has a strong impact on other areas such as water, human health, climate change, nature and biodiversity protection, and food safety. The soil strategy ensures that soils of Europe remain healthy and productive.

The propose of soil strategy is to establish a common approach across the EU, but leave national governments flexibility to implement this approach in a way which fits local situations best. Public authorities in EU countries will be required to undertake activities to tackle threats such as landslides, contamination, soil erosion, and sealing of soil 
wherever they occur, or threaten to occur. Soil Strategy for cross-border region will provide a framework for soil protection of sandy soil and through better organic matter management it will contribute to handle the challenges set by climate change. Soil degradation was identified as a pressure for water quality, but only with respect to erosion and contamination, but relevant information on organic matter decline, deflation, compaction and soil microbiological activities are limited. On the other hand, farmers receiving direct payments in the region are subjects to compulsory crosscompliance standards.

\section{General and specific objectives of the project}

The major threats to soil, as identified in the Thematic Strategy for Soil Protection, include: erosion, decline of organic matter, compaction and loss of soil biodiversity. Soil Strategy for Nyírség and Bihor takes into account all the different functions that soils can perform, variability and complexity of soils in the region, and the range of different degradation processes, while also considering socioeconomic aspects. The overall objective is the protection of soil and preventing further soil degradation. Technological information is vital in terms of enabling farmers to achieve improved agricultural productivity, to make effective use of the natural resources, increase their income, and produce quality food that is safe, accessible and available to all. The study identifies, describes and evaluates reasons that directly or indirectly contribute to the mitigation of the soil threats and measures taken by the farmers of the Nyírség region under Cross Compliance (CC) to improve the soil management.

The project has three main objectives:

1. The assessment of the soils in the 2 regions, the promotion of mitigating degradation, the enhancement of sustainable land-use, increasing the competitiveness of the 2 landscapes as rural regions

2. Mitigation of soil degradation and enhancement of environmental consciousness due to the soil assessment and better knowledge on driving processes

3. As a result of the above mentioned, the productivity and the competitiveness of the region may improve

As the region is characterised by increasing poverty and high natural reproduction rates, the sustainable management of soils is inevitable to maintain and enhance the subsisting capacity of the agriculture in this rural area, in order to decrease the migration of population masses towards overpopulated urban centres and also to mitigate social tensions. Specific goals include:

\section{Efficient dissemination of results among the target groups}

Elaboration of know-how of application of Sustainability Index (SI) Model for the 2 areas

Creation of database serving as basis for the SI model

Creation of maps using SI model for the 2 territories

\section{Better assessment of status and processes of soils in the 2 areas}

Databases and maps regarding the present status of soils Experiments, data and maps of processes on the 2 territories Optimal soil management and amelioration

Objectives of the project are served by conference, books published for farmers; newsletter published on best management practices. Results and proposals will also be published on the internet. These efforts will contribute to the protection of soils from further degradation, as threats of compaction, nutrient loss, wind-erosion, misuse, waterdeficiency etc.

\section{Short summary of the project activities}

Elaborating and applying the Sustainability Index Model for the Nyirség: The Sustainability Index Model aims to create variables easily identifiable to allow land use decisions in relation to subsidies and land use policy. It further allows for comparisons between soil cultivation methods, which aids the society to allocate resources to participatory approach based programs, environmental schemes and in policy making. Three factors, Condition (C), Impact (I) and Benefit (B) are weighted on a simple scale from 1 to $5 ; 1$ being positive and 5 being a negative effect of the land use. The current condition of the land is valued using site or land use specific methods (e.g. presence of A horizon, SOM, vegetation cover on rangelands). The impact (e.g. fertilizer pollution, danger of soil erosion) is valued separately and it considers different threats. The benefits of each practice are balanced against needs. Subsidies or aid can be determined and given if the SI meets certain criteria.

Examination and evaluation of the potential deflation in the Nyirség: In the first phase of the work the experts using the results of 50 formerly sampled soils and examining 50 more samples, thus creating a dataset containing 100 samples, undertake to evaluate the potential soil erodibility based on textures, and also to visualize the results on maps of erodibility while enhancing public access to data. Beside creating a map of erodibility based on soil textures (one feature), more sophisticated comprehensive maps containing few more features influencing the potential erodibility - will also be produced. The investigations include the determination of the critical wind velocity on different dry and wet soils (without vegetation) and on soils with different crops sown. The second-third parts contain field observations and measurements of soil erodibility and wind velocity at sites with different land-use, vegetation cover near Nyíregyháza, Kisvárda and Nagykálló using wind-velocity samplers. These investigations examine the role of shelterbelts of different types. In the 4th part of the investigations we create a database using aerial photographs to map and evaluate the shelter-belts, and try to give proposals for the enhancement and modification of the shelter-belt-system to create a comprehensive system enhancing the efficiency of 
the present status. Based on these examinations a digital potential map of erodibility will be composed.

The environmental assessment of the hydrological features of the Nyirség: Experts undertake to digitize data of monitoring wells and to evaluate the results using the created and purchased databases, in order to visualize the results on maps offering greater publicity. The first phase of work includes the evaluation of surface waters, canalisation processes, the capacity and present-day exploitation. The second phase comprises the examination of long-term ground-water trends, types of ground-water oscillations. A series of ground-water maps on the Nyírség is to be created: highest level ever, lowest level ever measured, 10 year averages, average of long-term minimums, average of longterm maximums, oscillation of ground-water levels calculated both on altitude above sea level and on depth measured from surface. In the third phase of our examination we investigate the connection between precipitation, surface water levels and ground-water levels, determining which factor from among the aforementioned 2 has greater influence on the latter at certain terrain types using the methods of mathematical statistics. A special task force will deal with the identification of inland water threat using satellite pictures and GIS methods.

Instruments of sustainable nutrient-management in Nyirség region: The goal of sustainable agriculture is to bring together people and resources, to promote an agriculture that is efficient, profitable, socially acceptable and environmentally sustainable for the indefinite future. The primary objective is to provide a model where the agricultural system and community are taken into account as a whole, in which agriculture is not separated from the natural ecosystem of a region. The most critical challenge is to consider the needs of agriculture and society, and to provide an educational environment for local inhabitants. Developing an appropriate crop rotation scheme is one of the most challenging tasks for sustainable agriculture. Green manure crops play an important role in regenerative soil conservation strategy. Green manure adds organic matter to the soil, assists in dissolving nutrients, brings up nutrients from the subsoil and improves the water holding capacity of the soil. The crop rotation system should improve soil condition by including deep rooted plants and plants with a fibrous root system, to improve the stability of soil aggregates. There is also evidence suggesting that an improved soil structure increases biological activity in the soil and enables plants to utilise soil moisture and nutrients more effectively. Crop rotation can also contribute to soil conservation strategy.

Amelioration of sandy soils in the Nyirség: Our aim is to investigate how the different properties of Nyírség sandy soil under different cultivation influence the quantity of soil microorganisms, quality components of microbes, as well as to the soil biological activities. In the course of laboratory investigation the quantity of total number of bacteria, numbers of microscopical fungi, some important physiological groups of bacteria, as well as some important soil enzymes' activity are in the focus. We investigate the effects of bentonite and bentonite+manure as soil amendments on the physical, chemical and microbiological properties of sandy soil. The bentonite contains high amount of mineral colloids, manure contains high amount of organic matter, so they can be used for amelioration of sandy soil. Fermented biogases will have increasing role in the future in substituting nutrients. Another possibility of supplying nutrients for sandy soils is the usage of compost. Mulch, organic matter, farmyard manure and microbiologically fermented products also have effect on nutrient-supply.

Soil erosion and agriculture on hilly regions: The Romanian project partner will examine the role of erosion on physical features of soils formed on slopes, the role of erosion on chemical features of soils formed on slopes, the effect of soil erosion on the hydrology and watermanagement of hilly areas. Activities include measuring soil loss caused by erosion, the effect of erosion on the productivity, developing agriculture and the application of fertilizers on mountain regions.

\section{Cross-border impacts}

The overall objective of the soil strategy is the protection and sustainable use of soil in Nyírség region, preserving its functions and preventing further soil degradation. Most important direct beneficiaries of the project are local farmers and their organisations were involved in the planning of the project. Indirect beneficiaries are those, who are living in the region and their local communities. Furthermore both countries can be considered indirect beneficiaries, if the results of the project provide possibility to enhance the agricultural capacity of the area, as migration processes (depopulation) and social tensions among the inhabitants will decrease offering a sustainable way of livelihood on the long run.

Despite the increasing soil degradation and its negative consequences on human health, natural ecosystems and climate change, as well as on rural economies, Hungary and Romania has no specific legislation on soil protection. Through its various work programs and activities - like conferences, field demonstrations, and publications scientists, administrators, policymakers and extension workers in the region are given not only the chance to share and exchange technological innovations in the field of agriculture, but also the opportunity to strenghten international technical cooperation with neighbouring countries. It is the first experiment ever to draw up a sustainable soil strategy based on EU directives, therefore its effect (adaptation) may be borderless. The impacts on soil are also regardless of borders especially in connection with surface, and subsurface waters.

\section{References}

1. Communication (COM (2006) 231): Sets the frame of the Thematic Strategy for Soil Protection. EU Brussels, 2006.

2. The proposal for a framework Directive $(\operatorname{COM}(2006) 232)$ : Establishing a framework for the protection of soil and amending Directive 2004/35/EC. EU Brussels, 2006 